\begin{tabular}{c} 
Volume and Issues Obtainable at Center for Sustainability Research and Consultancy \\
Journal of Business and Social Review in Emerging Economies \\
ISSN: 2519-089X (E): 2519-0326 \\
Volume 5: No. 2, December 2019 \\
ᄃSRᄃ \\
Journal homepage: www.publishing.globalcsrc.org/jbsee \\
\hline
\end{tabular}

\title{
Financial Determinants of Economic Growth of Pakistan: An Empirical Analysis
}

\author{
${ }^{1}$ Zaib-un-Nisa
}

${ }^{1}$ M. Phil Economics, Visiting Lecturer Bahauddin Zakariya Universit, Multan, Pakistan, znisa5214@gmail.com

\begin{tabular}{|c|c|}
\hline ARTICLE DETAILS & ABSTRACT \\
\hline History & \multirow{7}{*}{$\begin{array}{l}\text { The paper attempts to investigate the relationship between savings and } \\
\text { Economic growth of Pakistan by using the time series data from } 1972 \text { to } \\
\text { 2015. For empirical analysis, ordinary least square method is used. The } \\
\text { analysis is made in two parts. In the first part; descriptive statistics and } \\
\text { correlation matrix are described. In second part, multivariate analysis } \\
\text { explains how saving of Pakistan is determined by economic growth. This } \\
\text { study concludes that the employed labor force, gross fixed capital } \\
\text { formation and exchange rate have positive and significant influence on } \\
\text { real gross domestic product. Foreign direct investment and gross domestic } \\
\text { savings have negative but insignificant impact on real gross domestic } \\
\text { product. Keeping in view the role of savings and economic growth in } \\
\text { Pakistan. It is recommended that government should provide enabling } \\
\text { environment and fiscal incentives for enhancing the foreign direct } \\
\text { investment. This will increase the gross domestic product in the country. } \\
\text { For this purpose, the industrial and agricultural sectors of the country must } \\
\text { be stable. Moreover, there is a need of creating an investment friendly } \\
\text { business environment in Pakistan. }\end{array}$} \\
\hline dforn & \\
\hline Availablc & \\
\hline Key & \\
\hline & \\
\hline Remittances & \\
\hline $\begin{array}{l}\text { JEL Classi } \\
E 43, E 49, F 1\end{array}$ & \\
\hline
\end{tabular}

(C) 2019 The authors, under a Creative Commons AttributionNonCommercial 4.0

Corresponding author's email address: znisa5214@gmail.com

Recommended citation: Nisa, Z. (2019). Financial Determinants of Economic Growth of Pakistan: An Empirical Analysis . Journal of Business and Social Review in Emerging Economies, 5 (2), 305-314

DOI: $10.26710 /$ jbsee.v5i2.855

\section{Introduction}

Capital accumulation, covered all new investment in land, physical equipment and human assets idea improvement in health, education, and job. Investment by a farmer in a new tractor might also rise the whole yield of the vegetable. He can harvest however without appropriate transport facilities to get this greater yield to nearby industrial market. They had other less direct way to finance in a national resource. The installation of irrigation facilities might also extend the quality of a country's agriculture land by rising of yield per hectare. If 100 hectares of irrigated land can produce the same yield as two hundred hectares of non-irrigated land using the same other input. The installation of such irrigation was the equivalent of doubled the amount of non-irrigated land. Use of chemical fertilizers and the control of bugs with pesticides may be similarly favorable impact in increasing the yield of existing farm land. All firm of investment had many way of improving the quality of existing land resources. Human capital is also call non-material capital: the abilities, skills, training, education, knowledge, and health of human being are called human capital. Human capital is creative and productive resources for proper investment and operation of the project at low cost. We need the services human capital like technicians, engineers, administrators, doctor, and economists etc. It is most powerful sources of economic growth. So the quantity and quality of labor, output and marginal efficiency of capital can be increased. It needed to introduce new method in 
agriculture, transportation and communication and to build educational system. According to requirement of the people, when proper investment in health nutrition drinking water etc. health of the people improved and productivity also rise. A labor force means more efficient employees and overall population increase the potential size of domestic market. It depends on the capability of economic system to absorb and productively hire. These added employees ability in specially correlated with the rate and types of capital accumulation and the availability of associated elements which includes managerial and administrative abilities, with unchanged technology. The capacity of human and physical resources were to that enhanced the quality of the existing resources or investment in new resources. Technological means new techniques of production, the new technology consist of new knowledge and method which lead to the reduction in cost, better use of raw material and discovery of new resources, Firstly there was a time when old method of cultivation, old seeds were used in agriculture sector and as result per acre yield was very low but now due to moderns technologies like high yield seeds fertilizers tractors, threshers, harvesters, tube wells, insecticides and pesticides, per acre yield has increased. Modern technologies have created a green revolution in agriculture sector and eliminated the food shortage problem in the countries due to modern technology, cost of production decreases. Modern technology enables the firm to produce the goods at large scales and get external and internal economics of scale. Used to modern technology oil, gas, iron, gold, copper. Coal and silver had been explored and mixed the various input can make new commodities. So the modern technology brings improvement of quality of the products. Economic growth of any country may be observed by two factors; Economic and Non-Economic factors

Resources are un-utilized, under-utilized, and miss-utilized in the country. These resources are not properly utilized due to use of old techniques of production, the lack of capital, and small size of markets. In Pakistan cultivable land is being wasted due to limited irrigation facilities.

\section{Review of the literature}

A number of studies have been conducted related to savings and Economic development at national and international levels. In this section, we have reviewed few of them as follows.

In 2006, Hasnain and co-authors investigated the factors of saving on economic growth of Pakistan's experience during the period 1972 to 2003. Authors used data collected by Economic survey of Pakistan, State Bank of Pakistan, and world growth series during the years 1980-2003. To assess the long-run and short-run relationships, they applied the error correction model and Johansen multiple co-integration to the data. The study located that interest rate and growth rate per capita income had been positive effecting. The old and young dependency ratios, and inflation rate had been negative influencing national saving in the long-run and short-run. By taking 5 percent adjustment annually, the model converged towards long-run equilibrium, as the error correction term was found to be 0.05 .

In 2007, author Fasoranti for rural residents attempted to find the impact of rural saving mobilization on economic growth. From 5 villages of Nigeria, 100 respondents were studied by using questionnaire survey. Author made use of ordinary least square (OLS) technique. From the results it is found that investment, assets, and human capital were positive determinants to overall saving. He established that there is 98 percent of the variation in overall saving due to the determinants: investment, assets, and human capital. They recommended that to join co-operative societies, the rural dwellers should be appropriately trained.

In rural Vietnam, Newman et al. (2008) attempted to find the factors of household saving. From 12 provinces of Vietnam, 2324 households had been taken by Vietnam Access to resources household survey in 2006. The percent analysis was accomplished and they established that in rural Vietnam richer household had been more likely to save, negative effects of age of household head have been found, no education effects have been found, financial saving have been low, and share of formal saving have been relatively small. They recommended that Government should improve saving institutional framework.

In 2008, authors Sajid and sarfraz attempted to find the association among saving and economic development. Time series quarterly data was used by them from 1st region of 1973 to 4th region of 2003. The co-integration method and vector error correction method were used by them to observe causality between output and public saving. The result showed that there was long-run and short-run equilibrium association between different measures of saving and economic development. 
Kazmi (1993) made attempts to investigate the effect of different macro-economic variables on public saving in India and Pakistan. They utilized the combined data obtained from India and Pakistan for the year 1960 to 1988. The OLS approach was employed to assess the saving model. They concluded that export, External Aid inflows, real interest rate, Government expenditure, growth rate of real GNP, inflation rate, and term of trade exerted positive impact of public saving rate.

In 1995, Azhar investigated to deal with several aspects of rural savings. The researcher gave some evidence from different nations. They observed that in Pakistan rural households saved without considering size in their landholding and saving performance of rural households had been healthier than the National Average.

Brata studied the saving behavior of rural industry households. The researcher performed questionnaire based survey from sub-district of Bantul and collected data from 93 respondents. Their work showed that education, household income, and type of industry had direct effect on household savings. The role of industry and square of age in income had statistically non-significant effect on household savings. They recommended that Government must enhance rural industries to high savings and provide credit for rural industries.

\section{Data, Methodology, and Model}

The issues regarding data sources, methodology of the work and model specification are explained in following sections.

\subsection{Nature and sources of Data}

This section explains the nature and sources of data utilized in this study. In this study, all variables follows a time series as data is collected for the time period 1972 to 2015 . The annual data are collected from the hand book of statistic of Pakistan economy for the variables gross domestic savings, Exchange rate, foreign direct investment, gross fixed capital formation, and employed labor force. Some data is also acquired from the economic survey of Pakistan. The measurement unit of all variables in this study is in millions of rupees.

\subsection{Methodological issues}

The methodology investigates the savings and economic growth of Pakistan by performing a time series analysis. In econometric usually some methodological issue may present regarding the time series data. For example the issue of non-stationary time series, spurious correlation and regression. When issue of non-stationary exists or model fitted is spurious regression, then the results from OLS technique becomes inefficient. For the variables that are stationery at level I(0) or the Durban-Watson (DW) value is more than R2, then the OLS technique is beneficial and relevant. In this study, it is found that the variables fulfill the property of stationary at level $\mathrm{I}(0)$.

\subsubsection{Ordinary Least Square Method}

In 1974, Carl friend rich Gauss presented the technique of OLS. Under certain assumptions the least squares method has some important statistical properties which have made it one of the most popular and effective technique in regression analysis. The OLS technique is used to estimate the relationship of the variables. When all the variables in the study are all stationary at level $\mathrm{I}(0)$, then the mostly used technique is the OLS technique. In multivariate data analysis this techniques is also important. For this study, the multiple regression model takes the form as

$$
Y=\beta_{1}+\beta_{2} X_{2}+\beta_{3} X_{3}+\cdots+\beta_{n} X_{n}+\mu
$$

\subsubsection{Model Specification}

Model specification is depend upon multiple regression approach. the A log linear model is assumed as observed from the properties of the data,

$\mathrm{RGDP}=\mathrm{a}_{0}+\mathrm{a}_{1} \mathrm{GFCF}+\mathrm{a}_{2} \mathrm{GDS}+\mathrm{a}_{3} \mathrm{FDI}+\mathrm{a}_{4} \mathrm{EXR}+\mathrm{a}_{5} \mathrm{ELF}+\mu_{\mathrm{i}}$

\subsubsection{Description of the variable}

\subsubsection{Real Gross Domestic Product}

The GDP is a measure of income and output produced in an economy; in a specific period.

\subsubsection{Gross Fixed Capital Formation}

The GFCI can be predicted using three techniques; 
- Commodity flow method

- Expenditure method

- Financial technique

\subsubsection{Domestic savings Gross}

National savings are the sum of private savings and public savings

\section{Private savings}

Private savings is the distinction of disposable income and consumption.

\section{Public savings}

Public financial savings is the difference among authorities' revenue and government spending. The time period (T-

$\mathrm{G})$ is public savings. Public financial savings shown through the time period (Y-T-C)+(T-G)

\subsubsection{Exchange Rate}

The price of one U.S.A's currency in term of another U.S.A's currency is referred to exchange rate.

\subsubsection{Labour Force Participation}

The percentage of working-age population. Who are member of the labour participation.

\section{Results and Discussions}

The results from the analysis are done in two stages. In first level descriptive evaluation and empirical analysis is performed within $2 \mathrm{~d}$ level.

\subsection{Descriptive analysis}

Descriptive evaluation provides the basic information and distributional characteristics of the data utilized in the study such as, average, variance or standard deviation, minimum and maximum value of the data. It describes the degree of relationship between the variables. In Table 1, the first column is for variable names, the second column is about average of the variable and the next column contains the values of maximum, minimum and standard deviations of the variables. The table represents pair wise correlations among variables of the study. The variables are positively correlated with each other.

Table 1: Descriptive Statistics of the variable (in millions of rupees)

\begin{tabular}{|c|l|l|l|l|}
\hline Variables & Average & Max & Min & SD \\
\hline GFCF & 26.23865 & 28.98464 & 22.6421 & 1.727009 \\
\hline GDS & 25.81524 & 28.5638 & 22.30174 & 1.925151 \\
\hline FDI & 19.46292 & 22.44425 & 15.2018 & 1.78363 \\
\hline EXR & 3.390922 & 4.632486 & 2.161181 & 0.831734 \\
\hline ELF & 3.518162 & 4.050393 & 2.956991 & 0.31902 \\
\hline
\end{tabular}

Source: estimation using E-views statistical software

\subsubsection{Correlation Matrix}

The correlation matrix presents the strength of interdependence (degree of relationship) between variables. From the results of correlation matrix the presence of multicollinearity can be investigated. If the value of correlation between two regressors in absolute value is greater than 0.8 , then there may be a severe issue of multicollinearity among variables.

Table 2: Correlation matrix

\begin{tabular}{|l|l|l|l|l|l|l|}
\hline LGDP & 1 & & & & & \\
\hline GFCF & 0.998 & 1 & & & & \\
\hline GDS & 0.985 & 0.987 & 1 & & & \\
\hline FDI & 0.923 & 0.936 & 0.931 & 1 & & \\
\hline EXR & 0.987 & 0.980 & 0.983 & 0.899 & 1 & \\
\hline ELF & 0.991 & 0.987 & 0.960 & 0.906 & 0.97 & 1 \\
\hline
\end{tabular}

\section{Correlation matrix:}


Table 2 shows the values of Pearson's correlation among variables. This table presents correlation in matrix form, the GFCF has a strong positive relation with GDP. The GDS is positively and highly correlated with GDP, highly collinear with GFCF. The FDI is correlated with GDP, GFCF and GDS. The EXR is highly correlated with RGDP, GFCF, GDS, and FDI. The ELF is also highly correlated with RGDP, GFCF, GDS, FDI and ER.

\subsection{Multivariate Analysis}

The estimates from OLS method regarding savings and economic growth are shown in Table 3. The first column investigate the variables which are abbreviated in the form of GFCF, GDS, FDI, EX, and ELF. Column 2 shows the estimates of co-efficient of the model. Column 3 report the standard error, for the reliability of regression coefficient values the t-test is used and are shown in 4th column. The values of $t$-test are used to determine whether the null hypothesis may or may not be rejected at chosen significance level.

Table: 3 .

Savings and Economic Growth

Dependent variable LGDP

\begin{tabular}{|l|l|l|l|l|}
\hline Variable & Co-efficient & \multicolumn{1}{|l|}{ Std. Error } & \multicolumn{1}{l|}{ T. Statistics } & Probability \\
\hline C & 6.395414 & 0.569245 & 11.23491 & 0.0000 \\
\hline GFCF & 0.652193 & 0.067662 & 9.639055 & 0.0000 \\
\hline GDS & -0.0118 & 0.043652 & -0.27025 & 0.7885 \\
& & & \\
\hline FDI & -0.0255 & 0.014481 & -1.76123 & 0.0865 \\
\hline EXR & 0.410715 & 0.071503 & 5.74401 & 0.0000 \\
\hline ELF & 1.128539 & 0.224135 & 5.035085 \\
\hline R. Square & 0.99 & Observation & 43 \\
\hline Adjusted R. Square & 0.99 & \multicolumn{2}{l|}{ Prob (F-statistic) } & 0.00000 \\
\hline
\end{tabular}

The impact of GFCF on RDGP is found statistically significant and positive. The Capital formation performs a very vital role in the economic development. Capital formation has great reputation in labor surplus nations due to the fact in those nations there is high labor because of high population growth rate. The surplus labor may be transformed into human capital via skill growth and education. Resources may be converted into high productivity.

The coefficient of savings shows that GDS have statistically non-significant and negative impact on GDP in the short-run. The negative and lower value recommended that if everyone tries to save higher percentage of profit; it generates economic down turn since the savers will be power instead of becoming richer. This is because the economy will slow down from decrease in demand and due to that the same people will be cyclically unemployed. Therefore, increased savings represent a shrinking circular flow of income.

The value of regression coefficient for FDI is statistically non-significant and negative relationship. The FDI has negative effect on the development of the recipient economy if they provide boom to an enormous reverse flows inside the shape of remittances of profits, if sources are remitted through transfer pricing and dividends.FDI can lessen competition and development, if the government of host country affords greater safety and security to foreign investors to attract their capital. The dependency school theory asserts that foreign investment from developed countries is harmful to the long-term economic growth of developing countries. By extracting labor and other resources from the developing countries, it located that developed countries became rich. This sort of act reasons distortion delays growth and increase income inequality in poor countries. Diaz-Alejandro explained that foreign capital can decrease economic development by producing high profit in a country with trade distortions. In developing countries, Hien showed a non-significant effect of FDI inflows on economic development.

The coefficient of EXR is positive and significant effect on real gross domestic product. The EXR plays an vital role in the economic development. The association among the EXR and economic growth is virtually an important challenge, from each a normative and perspective viewpoint. Several developing countries that have implicitly and explicitly constant their ER to the forex of another united states and whose inflation costs are high than that of the foreign united states often experience persistent current account deficits and eventual devaluations of their currencies, devaluation everyday invitations a recession and inflation and pushes the economic system into an inflation devaluation spiral; inflicting a extreme setback in economic growth. Other developing countries grow 
incredibly fast and often face the alternative stress on their currencies. A excessive economic growth rate is most possibly accompanied by a high investment and excessive high export improvement as a success exports yield current account surpluses, resulting in nominal appreciation stress on the currency except the central bank mediates within the foreign exchange market and accumulates foreign reserves.

The ELF is another vital element that is persuading savings instantaneously. In the present study, it is determined that ELF has positive and statistically non-significant impact on real GDP. It means that the cause of positive impact of ELF can be that extra savings are made due to higher return on growth, The employment opportunities are created and eventually the market is prolonged due to investment and employment multiplier. With the help of improved manpower the natural resources are used, as oil and gas are determined.The result for the sample demonstrates that the growth is positively correlated to employment level and have a statistically significant relationship because as employment level develops, more human beings get jobs and the poverty level diminishes which in turn raise the growth level.

\section{Conclusion}

This study observe and examine the economic growth and savings in Pakistan using the data for the year 1972 to 2015. The result from the analysis focus on the importance of savings in order to enrich growth. The study concluded that the real FGC, ELF, and ER have significant and positive influence on real GDP. FDI and GDS have significant negative impact on real GDP. It is therefore, recommended that Government should offer permitting environment and financial motivations. It will enhance GDP in the country. Therefore, agricultural and industrial sectors of the country must be established. In Pakistan there is a need of supplying an investment friendly business environment.

\section{References}

Abdelkhale. K.T.Arestaff, F. Fritas, M.N. and mage,S.(2009). A micro econometric analysis of household saving determinants in morocco: university of parisDouphine PP : 1-7

Abel, A.B. and Bernanke, B.S. (2007). Macroeconomics. Dorling Kindersley (India) pvt .Ltd. licensees of Pearson education in south Asia. Fifth edition.

Agarwal, P. (2000). Saving, investment and growth in south Asia. Indra Gandhi institute of development Research, pp.1-47.

Ahmad ,H. M, Atiq, Alam, S., and bhutt , S.(2006). The impact ofdemography ; growth and public policy on household saving : case of Pakistan; Asia pacific development Journal,13(2), 57-71.

Ando,A. and Modigliani,F.(2012). The Life cycle hypothsis of saving;Aggregate Implication andtests.American Economics Review, 53, 55-84.

Anoosha, H,K. S.U.Rahman and Farrukh, B. (2015). External Sector and Economic Growth of Pakistan: A Time Series Analysis. International Research Journal of Social Sciences, 4(10),25-31.

Asghar, T,Andahmed,M. (2012).Estiamate of savingsBehaviour in Pakistan using micro data The Lahore journal of economics, 9 (2),73-92.

Azal. M,(2009).Population growth and economic development in Pakistan: open Demography Journal, 2,1-7.

Azam . M, M.khan ,Z.khan, shafiquallah,S.I. khan and A. qayyam. (2012) Significance of national saving in the socio-economic development of Pakistan: 1994-2009, Sarah J. Agric,26(3)PP 412-417.

Azhar, B.A. (1995). Rural saving their magnitude, Determinants and mobilization.The Pakistan development Review, 34(4), 779-788.

Baharamshah,A.Z; Thanoon, A.M; and Rashid.S. (2002) saving dynamics in the asaincountries;Journal of Asian economics, 204,1-19.

Benos, Nikos. (2004). Fiscal policy and economic growth:Empirical evidence from OECD countries

Brata, A.G. (1999), Household saving behavior the case of rural industry in Bantul. Analysis CSIS, 28 (1),75-86

Burney, A.N., and khan, H.A. (1992). socio economic characteristics and household saving;

Buscemi, A, Yallwe, H.A.(2012). Fiscal deficit National saving and Sustainability of Economic growth in emerging economics; a dynamic GMM penel data approach International Journal of Economics and financial issues Vol; 2 (2), 126-140

Cantor, R, and Yuengart, A. (1994).The Baby Boom Generation and aggregate savings." Federal Reserve Bank of New York Quarterly Review, 76-91.

Carrol, C. and Weil, D. N. (1994). Saving and growth: a reinterpretation. Carnegie-Rochester Conference Series on Public Policy, 40, 133-192.

Chaaudhry,S.I,(2007). Financial liberalization and macro-Economic performance: EmpiricalEvidence from 
Pakistan, 1-19.

. Chamon, M.D, and Prasad, E.S. (2010).why are saving rates of urban household in china Rising? American Economics journal,2 (1), 93-130.

Ciftcioglu,S,Karaaslan, C., and Demir, H. M.(2001). Saving, Investment, Export, Economic growth in Turkey. Review of Social, Economic and Business Studies, 3(4), 20-30.

21. Deaton, Angus,(1989). Saving in Developing Countries. Theory and Review. In Proceedings of the World Bank Annual Conference on Development Economics (pp 61-108). Washington, D.C: World Bank.

Dickey, D, and W. Fuller. (1981). Likelihood ratio statistics for autoregressive time series with a unit root.Econometrica, 50, 1057-1072.

Dimkpah, Y. O. (2002). The Stage of Economic Development, Export, and Economic growthand empirical investigation. The African Economic and Business Review, 3(1), 60-67.

Duesenberry, J.S. (1949), Income, Saving and the theory of consumption Behaviour Cambridge Mass,Harvard University.

Ekanayake, M.E.(1999). Export and economic growth in Asian developing countries co-integration and error correction Model Journal of Economic development, 24 (2), (43-56)

Engen,Eric. M, and Jonathan Skinner (1992),Fiscal and economic growth, "NBER" working paper 4223(Cambridge Massachusetts: National Bureau of economic Research).

Farhan, M, and Akram.M. (2009).Does income level effect saving Behavior in Pakistan: AnARDL approach to cointegration for empirical assessment: for east research center, 66-72.

Faridi,Z.M. (2012). Contribution of Agricultural export to economic growth in pakistan. Journal of commerce and social science,6(1),133-146:

Faridi,Z.M,Rehman, H, and Bashir,F. (2010). Household saving Behaviour in pakistan; A case of Multan district;Pakistan journal of social science (PJSS), 30 (1), 17-29.

Fasoranti, M.M. (2007).The influence of rural savings mobilization on Economic development of the rural areas: A study of AKOKA Region in ondo state in Nigeria.International Business Management ,1(2),20-23.

Feldstein, M. (1974). Social security, Induced Retirement, and Aggregate Capital Accumulation. Journal of political Economy, 82, 905-926.

Foul, A. (2010). the causal relationship between savings and economic growth, same evidence from MENA countries, (1-12)

Friedman, M.A. (1957). Theory of consumption Function. Princeton, N.J., Princeton University Press.

Gist, J, Wu, K, and Ford, C. (1999). Do Baby Boomers Save, If So, What For? Washington, D.C,AARP.

Govt of Pakistan. (2010-2011). Pakistan economics survey, Ministry of Finance. Islamabad.

Granger, C. (1969). Investigating Causal Relations by Economic Models and CrossSpectralMethods.Econometrica, 37(3), 424-438.

Granger, C.(1980). Causality Cointegration and Control. Journal ofEconomic Dynamics and Control,12, 511-559.

Granger,C.W,J. and P.Newbold.(1974). Spurious regression in Econometrics.Journal of Econometrics, 2(2),111120.

Griffith, R, Leibtag, E, Leicester, A, and Nevo, A. (2009). Consumer shopping Behaviour; How Much Do Consumers Save?" Journal of Economics Perspectives, 23 (2), 99-120.

Gudaro, M.A,chhapra, U.I, and sheikh.A.S.(2010). Impact of foreign direct investment on economic growth:A case of Pakistan.Journal of management and social science,(JMSS), 6(2), 84_92

Gujrati,D.N.(1995).Basic Econometrics. New York; McGraw hill, Inc.3rd Edition;

Hand book of Statistics. (2010). State Bank of Pakistan.

Hasnain, M, Atiq, Z., Alam, S., and Butt, M. S. (2006). The impact of Demography,Growth and Public policy on Household Savings: A case study of Pakistan.Asia Pacific Development Journal, 13(2), 57-71.

Horioka, C. Y. (2009). The (DIS) Saving Behavior of the Aged in Japan. National Bureau of Economic Research, Working Paper No. 15601.

Husain, A. M. (1995). Long-run Determinants of Private Saving Behaviour in Pakistan.The Pakistan Development Review, 34(4), 1057-1066.

Hussain (1999) Economic growth and unemployment: Empirical evidence from Pakistan. International Journal of Human and Social Science, 332-339.

Hussain.(2010).How much do consumers save? Journal of Economics perspection. 23 (2), 99-120.

Iqbal, Z. M, and Zahid,G. M.(1998). Macro-Economic Determinants of Economic growth in Pakistan.

Iqbal, Z.M,Ahmed.N, and Hussain, Z. (2010). Impact of saving and credit on economic growth in Pakistan. The Pakistan journal of social science, 32 (1), 39-48

Ismail, A., Zaman, K., Atif, M, R. Jodon, and Seemab, R. (2010). The Role of Exports inflation and investment and 
economic growth in Pakistan. 1(1), 1-9.

Jilani, sheikh, A, and Cheema,A.F. (2013). Determinants of National savings in Pakistan" An exploratory study: Asian social sciencevol: 1(1), 1-7.

Jiranyakul, Komain\&Brahmasrene, Tantatape. (2007). The relationship between government expenditures and economic growth in Thailand:

Kazmi, A. (1996). National Saving Rates of India and Pakistan: The Macroeconometric Analysis. The Pakistan Development Review, 34(4). 1313 - 1324.

Kemal,A.R. (1997). Pakistan foreign Debt Perception and Reality. Pakistan Bankers, 7(2), 58-65.

Kenrick, C.H.(2004). Remittances, Remittances Decay and Financial Deepening inDeveloping Countries. The American Economist, 48(2), 82-94.

Keynes, J.M,(1936). The general theory of Employment, Interest and Money.

Khan .T, Gill, R.A, and Haneef .S. (2013). Determinants of private saving : case of Pakistan.

Khan, D, Maryam, a, zaman, N.ahmad .E, and Shoukat. (2012). Export, import and economic growth nexus , time series evidence from Pakistan, World Applied science journal,18(4), 538-542.

Khan, M.S.(1993). Domestic Resource Mobilization; A Structural Approach.The Pakistan Development Review, 32(4), 1067-1078.

Khan,Z, Naheed and E. Rahim. (1993). Foreign Aid, Domestic Savings and economic growth (Pakistan: 19601988). The Pakistan Development Review, 32(4), 1157-1167.

Khostakis. (2011). The determinant of household saving during recession: Evidence from Greece, 1-9.

King,M.(1985).The economics of savings: A Survey of Recent contribution. In Frontiers of economics. Edited by K. Arrow and S. Houkapohja. New York, Basil Black, 227-294.

Lewis, W.A. (1955). The Theory of Economic Growth. Homewood, III: Irwin.

Loayza, N,Schmidr-Hebbel, K, and Serve, N. (2000). Saving in developing countries: An Overview.The world Bank Economics Review, 14 (3), 393-414.

Lucas, R. (1988). On the Mechanics of Economic Development.Journal of Monetary Economics.

Mahmood, Z,andQasim, M. A. (1992). Foreign Trade regime and Saving in Pakistan. The Pakistan Development Review, 31(4), 883-893.

Mankiw, G.N.(1996). Macro-economics, Harvard university: Worth publishers, 5thedition.Parkin, M. (2002). Economics, Addison Wesley, Seventh edition.

Mashkoor, M, Yahya, S, and Ali, A. S. (2010). Tax revenue and economic growth.

Modigliani, F. (1986). Life Cycle, Individual Thrift, and the Wealth of Nations," American Economic Review, 76, 297-313.

Mohan,R. (2006). Causal relationship between saving and economic growth in countries with different income level. Economics Bulletin, 5 (3),1-12.

Mohey-ud-Din, Ghulam, (2006). Impact of foreign capital inflows (FCI) on economic growth inPaskistan (19752004). Journal of independence studies and research, 1 (5), 22-29.

Mullick, H. (2004). US Foreign aid and Economic growth. Pennsylvania Economic Association Conference.1-28.

Nasir, S, and Khalid, M. (2004). Saving-Investment Behavior in Pakistan. An EmpiricalInvestigation.The Pakistan Development Review, 43(4), 665-682.

Rais, I.S, and Anwar.T, (2012). Public debt and economic growth in Pakistan. Time series Analysis: academic research international, 2 (1), 535-544.

Romer, P.M. (1986). Increasing returns and long-run growth.Journal of Political Economy, 94, 1002-1037.

S.U. Rahman., A. Hussain and M. Taqi.(2014) Impact of agricultural credit on agricultural productivity in Pakistan: An empirical analysis. International Journal of Advanced Research in Management and SocialSciences, 3 (4) (2014), 125-139.

Shabbir, T, and Mehmood,A. (1992).The effect of foreign private investment on economics growth in Pakistan.The Pakistan development review, 31 (4)

Sheikh , R. M, Faridi , M.Z, and Tariq. K. (2012).Domestic debt and economic growth in Pakistan:An empirical Analysis.Pakistan Joural of social science, (PJSS), 2(2), 373-387.

Sheikh, R.M. (2009). Economics of Pakistan. Liberty Book Centre, (2008-2009) Edition.

Siddiqui,R, and Malik, A. (2002). Debt and Economic growth in South Asia.The Pakistann Development Review, $40(4), 667-668$

Singh, T. (1988). Does domestic saving cause economic growth.A time-series evidence from India.

Solow, R. (1956). A contribution to the theory of economic growth. Quarterly Journal of economic, February.

Swan, T. (1956). Economic Growth and Capital Accumulation.Economic Record,32(4), 334-361.

Tang, C. F, and Lean, H. H. (2009). The Effect of disaggregated, saving on Economic growth in Malaysia: 
Generalized various decomposition analysis.Asian Business and Economic Research paper, 9(4), 1-14.

Tiwar; K.A, and Mutascu. M. (2011). Economic growth and foreign direct investment in Asia. A panel data approach economic analysis policy, 41(2), 173-187.

Toda, H.Y, and Phillips, P.C.B. (1994). Vector Autoregressions and Causality: A Theoretical Overview and Simulation Study", Econometric Reviews, (1)259-285.

Todarro, P. M. (1990). Development economics" Addison Wesley, eight editions.

Ullah, S,Azim, P, and Siddique, W. (2012).Impact of foreign and volatility and economic growth in Pakistan.

Verma, R. (2007). Savings, investment and Growth in India. South AsiaEconomic Journal, 8(1), 87-98.

World Bank, World Development Report: Washington D.C. Oxford University Press.

Zaman, K.M. (2010). Female Enrolment rate and Economic growth in Pakistan: Is there causal relationship. 3rd International Conference on assessing quality in higher Education, $322-337$. 
